\title{
Sublimidade do Mal e Sublimação da Crueldade: Criança, Sagrado e Rua
}

\author{
José Francisco Miguel Henriques Bairrão ${ }^{12}$ \\ Universidade de São Paulo
}

\begin{abstract}
Resumo
A partir de uma ocorrência contemporânea, revisita-se a tese de que a Umbanda reflete processos históricos e guarda memórias sociais profundas. Há indícios de que esse talento vem sendo aplicado à reflexão do abandono da infância, orientando práticas de cuidado e de solidariedade retribuidoras de dons atribuídos ao "povo de rua" infantil, embasadas no reconhecimento da sua participação e inserção "mística" na vida social. Neste artigo analisam-se performances rituais de "exus mirins" e depoimentos desses personagens do panteão umbandista e dos seus fiéis, supondo-se que dar ouvidos a essas meditações coletivas e ao modo como espelham o curto circuito entre sociedade excludente e ferocidade infantil contribua para compreender como os setores que mais cedem vidas a esse horror o interpretam e se significam. Conclui-se que, por meio da inclusão profunda das crianças de rua no âmago da experiência religiosa, a Umbanda contraria a sua segregação e extermínio, físicos e simbólicos.

Palavras-chave: Meninos de rua; etnopsicologia; memória social; psicologia e religião; Umbanda.
\end{abstract}

Sublimity of the Evil and Sublimation of the Cruelty: Child, Sacred and Street

\begin{abstract}
The observation of a contemporary occurrence led to the reconsideration of the thesis that Umbanda reflects historical processes and holds deep social memories. There are indications that such resource has been applied to the reflection of childhood abandonment, guiding care taking and solidarity practices that retribute the talents attributed to child "street people", based on the recognition of their participation and their "mystic" insertion in the social life. This article aims at analyzing ritual performances of "Little Eshuses" and statements of these umbandist pantheon's characters and of their followers. It is supposed that lending an ear to these collective meditations and to the way they reflect the short circuit between the excluding society and the childhood ferocity contributes to the understanding of how the sectors which most give away their lives to such horror interpret it and signify to themselves. It is concluded that Umbanda thwarts segregation and extermination - both physical and symbolic - of those children by means of their deep inclusion in the heart of religious experience.

Keywords: Street children; ethnopsychology; social memory; psychology and religion; Umbanda.
\end{abstract}

O imaginário umbandista integra o universo da mentalidade popular e tem uma consistência semiótica, cuja realidade é reconhecida pela generalidade dos brasileiros, inclusive pelos pouco afeitos às suas manifestações. É sua tradição incluir experiências sociais traumáticas, estabelecendo orientações quanto ao tratamento dos seus reflexos e elevando-as a símbolos religiosos aclimatados ao contexto brasileiro, os quais articulam relações de identificação e de participação entre contemporâneos e matrizes históricas que circunscrevem as suas condições existenciais (Concone, 1987, 2001; Negrão, 1996; Prandi, 1991; Souza, 2001). Desta forma, a Umbanda reflete tipos e experiências sociais, estabelecendo padrões para o tratamento de traumas coletivos e incluindo na geografia social e imaginal brasileira dimensões do humano maltratadas.

\footnotetext{
${ }^{1}$ Auxílio FAPESP Processo 02/01653-3. Sou grato a todos os exus mirins que colaboraram com a pesquisa, bem como às autoridades espirituais e materiais umbandistas que a consentiram. Agradeço igualmente aos pais e filhos de santo das Tendas de Umbanda Cacique Pele Vermelha e Soldados da Mata e da Fraternidade Espiritual Caminhos de Oxalá, bem como aos "cavalos" de um dos Porteirinhas, do Mirim da Árvore da Beira do Caminho e do Girinho, no momento sem vínculos com terreiros.

${ }^{2}$ Endereço para correspondência: DPE-FFCLFP, USP, Campus de Ribeirão Preto, Av. Bandeirantes, 3900, 14040 901, Ribeirão Preto, SP. E-mail:jfbairrao@ffclrp.usp.br
}

A não codificação do culto e o seu distanciamento de formas mais "puras" e tradicionais de religião, que poderiam de um ponto de vista valorizador da (imutabilidade da) tradição serem entendidas como defeito, para efeito deste tipo de pesquisa são virtudes, por indicadoras de maior adaptabilidade ao murmúrio social.

Portanto, do ponto de vista de uma investigação social que tome o sagrado enunciante como parceiro na tarefa de cuidar do humano, a Umbanda apresenta um grande interesse, por mais aberta e plasticamente dócil ao "sopro do espírito". Dito de outra forma, é mais permeável e plasmável pela interpelação do humano por um Outro.

Dar-lhe ouvidos independe de decisões quanto aos significados supostos à realidade deste Outro (isto é, não implica tomar partido no âmbito do território da metafísica e da ontologia). É possível e recomendável manter a interlocução com o "seu" imaginário estritamente num âmbito humano, aberto ao semelhante e também disposto à alteridade, abstendo-se de formular juízos de realidade sobre os seus conteúdos.

Com esta pesquisa averigua-se o que esse repertório espiritual popular nos pode revelar a respeito do acolhimento e compreensão profunda do drama das crianças de rua, na 
medida em que essa tragédia atualmente de certa forma nela é socialmente refletida, por meio do desenvolvimento e evolução de uma personalidade do panteão, antiga e rara, em categoria geral, nova e cada vez mais freqüente, de espíritos ritualmente cultuados (os exus mirins). Tem-se hoje, portanto, uma oportunidade impar para verificar ao vivo, como acontecimento presente, um processo psicossocial anteriormente descrito, retrospectivamente, a propósito de categorias de manifestação do sagrado previamente bem estabelecidas.

Neste caso, o desafio enfrentado é o de abrigar um sentido para a crueldade contra a criança e para a maldade infantil. Trata-se em especial de reconhecer semelhanças entre outros maus e possibilidades intrínsecas do humano, que também podem ocorrer "contra" nós (cada um e o grupo), ou, mais difícil ainda, a partir de nós. Pior, já aconteceram, uma vez que os umbandistas levam a sério a idéia de uma comum responsabilidade e da interligação de destinos.

Como é usual neste cenário religioso, evidencia-se também neste caso uma ética de inclusão profunda (Brumana \& Martinez, 1991), ressocializadora, que retrata e admite, sem oprimir nem pré-requisitar reformulações. Compreende.

Mas assim como aceita e sublima o mal (incorporando-o ao humano e atribuindo-lhe qualidades e funções), também espelha e reconhece o medo que ele provoca, o que se reflete em hesitações, temores, e mesmo na recusa ao trato ritual com essas "crianças metafísicas" endiabradas. A exclusão social chega a refletir-se em processos de exclusão ritual, que não podem ser avaliados de maneira maniqueísta, por em última instância espelharem a dificuldade, verdadeira, de inclusão em profundidade de infâmias, desesperos e horrores viscerais.

Para sondar psicologicamente esse imaginário coletivo, suspendeu-se o juízo de realidade e tomou-se ao pé da letra o que o dinamismo do seu simbolismo permite depreender, confiando à diacronia das suas manifestações o desvendamento do seu sentido. O recôndito do seu mistério elabora-se refletido nas entranhas do humano. Confia-se na sua estrutura para trazer à luz o outro lado do espelho imaginal (Corbin, 1977a, 1977b, 1979, 1981, 1990), ou seja, as formas inconscientes de compreensão social da experiência social (Bairrão, 2001).

Decifrando-as, torna-se viável articular políticas públicas e propostas de intervenção que se aliem ao coletivo, concebido como sujeito ativo na tomada de medidas a respeito de si próprio, em vez de o colonizarem com boas intenções.

\section{Método}

No contexto religioso, o imaginário - ou imaginal, conforme prefere Corbin (1977b) - apresenta-se como interface entre uma diferença radical, misteriosa, e um espelhamento em profundidade do humano, que se lhe dirige e que interpela (Corbin, 1977a, 1977b). Enunciante, o sagrado só pode revelar-se narrando o humano. Performances rituais e narrativas religiosas constatam-se preciosas aliadas do estudo do social e psicológico (Bairrão, 2002).

Bem mais do que um arquivo de símbolos, o imaginário religioso, ainda que irredutível, também é uma enunciação social e inconsciente. Dar-lhe ouvidos permite sondar em profundidade o popular, tratando-o não como coisa objetiva, mas enquanto interlocutor capaz de expressar elaborações cognitivas coletivas, revelar os processos que presidem à sua construção, e fornecer orientações para a sua decifração.

O estatuto empírico da sua investigação não depende de informantes individuais nem das suas crenças. Provém de uma rede "objetiva" de sentidos, consubstanciada num como que mundo intermediário entre o puramente espiritual e o material (Corbin, 1981), âmbito de intersecção em que se "sensorializam" idéias e se "espiritualizam" corpos (Corbin, 1979), e que pode ser interpretado não metafisicamente como uma linguagem visceral e poética, por um lado estruturada em moldes muito precisos, e por outro ressoante da experiência humana profunda - aquela mesma que se "insulariza" nas vivências psicológicas particulares, psicanaliticamente auscultadas nos consultórios, graças à sua elaboração e reconhecimento por conceitos como fantasia e sujeito pulsional (Bairrão, 2000).

A sua escuta processa-se prestando atenção a performances comunicativas não exclusivamente verbais e apóia-se em conceitos psicanalíticos como "fenômeno transicional" (Winnicott, 1975, 1990) e "significante" (Lacan, 1966) e antropológicos como "pessoa" (Duarte, 1984; Dumont, 1977/2000a, 1983/2000b, 1992/1997; Goldman, 1984, 1996; Mauss, 1968).

Uma plataforma viável para aplicar este método de investigação ao contexto brasileiro é a Umbanda, por esta ser extremamente maleável e sensível aos processos psicossociais - conforme autores como Prandi (1991), Trindade (1985), Souza (2001), Concone (2001,1987) e Negrão (1996), entre outros, tiveram oportunidade de verificar e demonstrar.

No presente estudo ouviram-se, suspendendo-se juízos de realidade e ao pé da letra, narrativas de crianças de rua espirituais e registraram-se depoimentos de religiosos que com elas convivem, no intuito de alcançar uma radiografia profunda da compreensão social e inconsciente deste drama antigo, mas agudamente contemporâneo. O levantamento foi feito com umbandistas "avulsos" (no momento sem filiação a nenhuma "tenda") e em três terreiros que admitem esta relativa novidade no culto, situados na Grande São Paulo e sem vínculos entre si. 
As narrativas que as revelam - registradas em áudio ou audiovisualmente e preferencialmente relatadas por elas mesmas ("incorporadas" em religiosos em estado de transe) e comentadas pelos seus fiéis - concomitantemente expõem aspectos da vida social e psicológica dos médiuns, articulam solidariamente aspectos da vida comunitária, e são codificações mais ou menos cifradas de práticas rituais. Fundem o humano e o sagrado em "mitos" pessoal e coletivamente elaborados, comportando uma presentificação da experiência do numinoso, reflexivamente humana, na forma de categorias gerais do panteão que se "encarnam" em identidades concretas.

O fenômeno nosso "objeto" de estudo é em si mesmo uma forma de conhecimento e de reconhecimento sociais. As “coisas" narradas são, antes do mais, significantes. Ressoam o corpo social e interpretam vivencialmente possíveis e dramáticas epopéias humanas, que têm algo a dizer a respeito de destinos e da condição humana postos em situações existenciais limites e em risco.

Portanto, compreendidos como narrações ritualmente dramatizadas, os nossos "dados" apresentam-se imediatamente como relações de sentido imanentes ao próprio campo investigado, constatadas na forma de repetições nuançadas, insistências e temáticas comuns aos testemunhos dos nossos colaboradores. Assim os ouvimos e por isso a apresentação dos resultados já se apresenta ordenada compreensivamente, conforme se mostram no contexto imaginal investigado.

Denominamos de dar ouvidos ao Outro a disponibilidade para resgatar as nuances e literais ressonâncias do que essas narrações nos informam sobre vivências e memórias psicossociais profundas, bem como as interpretações das suas razões e prescrições quanto aos remédios éticopolítico-religiosos que poderiam sanar as mal ditas mazelas que afligem o corpo social brasileiro. Fazemo-lo sem a preocupação (descabida) de formular pré-juízos quanto à realidade dos "fatos" (imaginais) narrados.

\section{Resultados}

\section{Os Exus Mirins}

Os mirins refletem a delinqüência infanto-juvenil das crianças de rua, sem disfarces ou recondicionamentos. Propõem-se como antípodas da beleza, inocência e pureza infantil (típica das crianças da "direita"). Geralmente são descritos como muito feios. A feiúra metaforiza esteticamente o lado "errado" da vida pelo qual trafegam (ou trafegaram).

Segundo uma mãe de santo, "uma característica deles é perigo à vista, como as crianças de rua. Carentes, têm a sensibilidade deles, mas oferecem perigo. Eles estão com medo, mas fazem com que você tenha mais medo do que eles, para intimidar, exatamente como um moleque de rua".
A sua periculosidade é apresentada como talento (como de fato o é e assim a compreendem, espelhando os recursos que permitem às crianças de rua sobreviver). Fiel ao seu "ethos", a Umbanda vai elaborar estas crianças que se defendem assustando, intimidando, e podem de fato ferir, socializando as suas "defesas". Transformando a sua competência ofensiva em qualidade defensiva. Descobre virtudes nos seus defeitos, inclui-os, sem pré-condicionar que isso se faça ao preço da anulação do modo de ser que se lhes tornou constitutivo (o que seria mais uma forma de violência, típica de outros cenários do menu religioso brasileiro, determinados por vocações doutrinadoras ou conversoras, umas e outras tentativas de supressão do diferente e da especificidade).

Moleques em fase de auto-afirmação, são fortes e gostam de mostrar serviço. Geralmente exibidos e fanfarrões, são imprevisíveis, temerários, ágeis, mutantes e desafiadores da autoridade. Empenham-se ao máximo para provar que são capazes e obter aprovação, o que aumenta a sua presumida periculosidade.

Por serem crianças, supõem-se pouco acessíveis a argumentos racionais e, pequenos, capazes de entrar em brechas mínimas em que ninguém pode alcançá-los (frestas que, concomitantemente, se compreendem como lugares metafísicos e como mínimas rugosidades do caráter alheio e/ou feridas psíquicas mal cicatrizadas...).

As suas giras habitualmente são ainda mais hilariantes do que o habitual numa religião que, com o povo brasileiro, aprendeu a referir solenidade a opressão. Mas bocudos, jocosos, facilmente descambam para gozações que, ainda que verdadeiras, podem ser ferinas. O senso da dor, própria e alheia, ou mais exatamente o senso de medida, parece passar ao largo das suas cogitações.

Conta-nos a mesma mãe de santo que "o prazer deles é pegar uma ferida da pessoa e torcer, para todo o mundo ver. Não têm respeito nem limite. Não é para prejudicar, mas revelam a vida, sem ter por onde escapar. Quando a pessoa percebe, está lá exposta".

Noutro terreiro dizem-nos que adoram bater papo, mas “... conselhos, só de sacanagem...”. Para evitar problemas é preciso mantê-los ocupados, "dar-lhes trabalho". Esta seria a chave para manter alguma disciplina ritual: "Se ficarem à toa, vira bagunça com certeza". Apreciam-nos e sabem que, ligeiros, uma hora parecem estar brincando, logo estão trabalhando, num instante seduzem, no momento a seguir implicam. Podem passar de uma coisa para outra e trocar de assunto tão rapidamente que é muito difícil acompanhá-los.

A médium do Girinho conta-nos que ele, muito ágil, pode incorporar-se nela e ao mesmo tempo "trabalhar" à distância. Faz sumir e aparecer coisas, como um saci. Adora chocolate preto e fuma cigarro. Em vida praticava pequenos 
furtos pelas ruas e gostava disso. $\mathrm{O}$ seu menino lhe passa algo "leve, engraçado, bagunceiro, atentado, peste". Relatanos que ela também tem um lado "mauzinho", "atentado", mais exatamente implicante do que malévolo, que se reflete na natureza dele. "A energia dele é a de transitar no submundo numa boa". Uma "criança vivida, safo, safado", mas não propriamente maligna nem malévola. Nunca o viu em pé.

De fato, nas suas giras, pudemos testemunhar que o mais habitual é que se apresentem sentados em rodinhas.

Ágeis para fugir, esconder-se, ou atacar, estão sujeitos a atropelos. Não é raro que tenham pernas quebradas, um superlativo da exclusão: postos na rua, excluídos, ficam "sem pé”. Faltam-lhes até pernas e pés, os meios que os adequariam a uma pertença aos caminhos, a uma vocação para o perambular, do ponto de vista do culto umbandista tão consubstancial ao específico das linhas de "esquerda", às vezes chamadas de "povo de rua", que nesse universo religioso os abrigam. Estão fora de lugar, mesmo no lugar de fora (a rua), o que parece ser uma condição do tipo, ecoando metaforicamente destinos sociais semelhantes.

Recentemente, num dos terreiros estudados, um deles teve as pernas quebradas, ao tomar a frente para amortecer uma batida de carro. Um dos Porteirinhas que conosco colaboraram "foi visto" por familiar da médium como um menino sem pernas (perdidas em atropelamento que o levou à morte). Na Casa da Priscila (Soldados da Mata) um deles não tem pé: diz-se que o perdeu na linha do trem. Amarraram-no aí e não conseguiu escapar.

"Ficar sem pé", "quebrar as pernas" (ser submetido a um constrangimento insuportável, ser impedido de cumprir um desígnio), são metáforas muito comuns, que parecem aplicar-se com muita propriedade às vivências sóciopsicológicas refletidas por estes "espíritos" e que certamente por isso se mostram e repetem à exaustão nas suas histórias.

Por mais que lhes "quebrem as pernas", são ágeis e ardilosos. Quanto mais lhes cortam as voltas, mais se põem a andar em paragens inesperadas. É-lhes intrínseco infiltrarem-se e invadirem territórios alheios, sendo este um dos seus talentos. Melhor, é próprio da sua reflexão de uma reatividade de excluídos "vazar" para quaisquer espaços.

Não é qualquer "entidade" que consegue trabalhar em sintonias tão fora e antagônicas à sua, e os mirins cometem regularmente essa proeza. Conseguem inclusive penetrar no espaço simbólico e ritual privativo da sua antítese no panteão, os "anjinhos" da direita, igualmente crianças, mas do ponto de vista da religião, antagonicamente distintos. Chegam a freqüentar as suas "giras", ocupar os seus jardins e papar as suas guloseimas. Nessas ocasiões acabam por se trair por as suas brincadeiras mais "pesadas" os deixarem isolados no espaço ritual (as crianças celestiais trabalham em união e a sua agitada alegria não "incendeia" o terreiro). Mas, sublinhe-se, no seu contexto, tais "defeitos" são uma sua grande qualidade.

O Mirim do Trevo ilustra esse talento. Várias vezes "vinha" na linha de Cosme. "Passava pelo dito erê". Dava um nome de erê e se "infiltrava". Brincava junto com os cosminhos ("brincava não, judiava"). Viveu no começo das ferrovias. Os trens tinham janelas sem vidro. Morava com a tia, largado. $\mathrm{Na}$ “arte de não obedecer", sentou numa janela e, num trevo, caiu e foi atropelado, esmagado nos trilhos.

Esta possível crônica da realidade da infância suburbana exemplifica notavelmente o talento da linguagem umbandista para incorporar uma interpretação do sagrado nas histórias aparentemente mais mundanas. Certamente não é à toa que na sua biografia aparece o ferro e muito especialmente na forma dos caminhos de ferro (Ogum e Exu, caminhos, ferro e trevos). Uma tradição religiosa africana, em vez de se dependurar numa mitologia estática, repercute e reencarna esteticamente num cenário urbano brasileiro, contemporâneo e trivial, e numa possível vida comum de uma criança desamparada. $\mathrm{O}$ anonimato e banalidade de muitas mortes são resgatados num ponto de celebração religiosa e uma espécie exemplar de biografia infeliz é elevada a condição de "encantamento" e estatuto de especialidade religiosa. Concomitantemente, as presumíveis funções rituais deste "menino" estão poeticamente explicitadas. É possível reconstruir este triplo nível de significação em todos os casos, bastando para tal alguma familiaridade com o repertório umbandista. Mas sublinhe-se que muitas vezes esta revelação de significados fica em plano secundário no culto, subtraída de qualquer destaque, pelo predomínio do fazer acontecer, pela valorização de efeitos pragmáticos, acima de atitudes contemplativas e de pendores especulativos.

Espetaculares, os mirins podem fazer-se notar de muitas maneiras, tão mais necessárias pela pouca disposição para vê-los ou admiti-los, como se a persistência das crianças de rua em invadir e ocupar espaços sociais, lembrando em cada farol e esquina a sua existência, se reproduzisse em "aparições" dos seus duplos "metafísicos". Quando isso acontece, quando acontecem essas "provas", para os umbandistas é um grato acontecimento.

Tais manifestações podem assumir inúmeras formas, ora tomando carona em fatos da vida social, ora recorrendo ao extraordinário. Um Porteirinha, por exemplo, mostrou-se a uma consulente, que o viu "fisicamente", como criança com cabelos de fogo vermelhos (caipora?).

$\mathrm{Na}$ Casa da Priscila, uma vez, quando o terreiro estava na praia (Bertioga), saiu um menino muito pretinho do meio de uma partida de futebol na areia e veio na direção dos médiuns com um largo sorriso. Todos viram. Ao lhe perguntarem quem era, apresentou-se, sempre sorrindo, 
como Zeca Capetinha (chefe do bando desse terreiro). Deu meia volta e retirou-se para o meio do jogo, e lá se esfumaçou. "O erê fez uma materialização coletiva na praia e todo o mundo viu".

Doutra feita, durante uma entrega de comida para "povo de rua", um dos parceiros do mesmo grupo, o Navalha, mostrou-se agressivo e cobrador, mas na forma de uma criança de verdade, esquálida e arruivada como ele, irritada por estar recebendo uma sopa, quando queria macarrão. Encarou a pessoa que lhe entregava a comida e ameaçou-a com uma navalha, dizendo: "você não tem medo de morrer, não? Eu não sou deste mundo". Tinha o rosto cortado tal e qual como o Navalha. Era o próprio, bem franzino, um toquinho.

Em vez de ameaça, a presença de um menino tão igual a uma entidade é imediatamente interpretada como sua manifestação e tempera o respeito e o medo com acolhimento e gratidão.

Fica patente que padecem de falta ou descaso de pai e ou mãe. Não é incomum a vinculação destas crianças a distorções ou carências das funções paterna e materna. Há especialmente uma associação delas a um feminino mais erótico do que maternal.

O Mirim da Mata da Beira da Estrada, por exemplo, em vida "não tinha pai, não tinha mãe. As prostitutas o adotavam e ele era abrigado pelas prostitutas. Vidinha dele era essa, no prostíbulo, nas ruas... Batia a carteira dos clientes das prostitutas". "Passava fome, passava frio". A médium acredita que morreu com sete anos. Já o "viu”. É "bem mulatinho". Não tem dente. Usa calça até à metade da canela, preta (talvez de sujeira) e camisa azul escura. Tem um cinto com rabos de gato. "A brincadeira dele era cortar rabo de gato, pegar sapo perto da represa" (observe-se, de passagem, a admissão da crueldade infantil, na forma bastante comum do seu exercício contra animais).

Como ele morreu? "Estava com fome, tinha saído do prostíbulo em que era protegido, entrou num armazém, roubou o que comer. $\mathrm{O}$ dono do armazém saiu atrás dele com uma faca. Saiu correndo e subiu numa árvore. Quando ele chegou num galho alto, o galho quebrou e ele morreu, da queda". Como é sempre o caso nas histórias umbandistas, carregadas de símbolos e sentidos encenados na forma de prosaicas existências comuns, também neste a vida narrada e a serventia mágica do "espírito" resumem-se no instante da morte. Uma vida de quebra-galho finda-se com a quebra de um galho. Ao pé da letra. A isso se deve o seu nome de Exu Mirim da Mata da Beira da Estrada.

Observe-se a sutileza implícita, numa narrativa a princípio meramente descritiva, da morte como queda (numa religião que supõe a imortalidade do espírito, o realmente "morto" é o decaído).
Onde tem pomba-gira, este exu mirim está junto. "Trabalha" com qualquer pomba-gira. Em vez do lar e da mãe, a rua e a puta.

$\mathrm{Na}$ Casa da Priscila um deles enojava-se de uma pombagira e veio a descobrir-se a razão: ela havia sido a mãe que o abandonara.

Priscila foi a distinta dona de um bordel no Rio de Janeiro da primeira metade do século passado. Hoje comanda a linha de pomba-giras de um dos terreiros colaboradores da pesquisa (Soldados da Mata). Na sua casa, os moleques são definidos pela mãe de santo como "bando de crianças de rua abandonadas que não sabem quem é a mãe, quem é o pai. A mãe é prostituta, a mãe matou o pai". Confirma-se que "eles mesmos satirizam a história deles. Colocam-se como se fossem o bom, em glória, porque roubavam, porque tomavam droga, porque fugiam da polícia". Tipicamente adolescentes, o seu assunto é "sexo e drogas".

Quase todo o bando desse terreiro tem origem carioca. Refugiavam-se no prostíbulo quando estavam doentes ou para esconder-se. Lá, seu grande prazer era espiar a nudez feminina. Certa feita, o Gordo da Encruza foi descoberto e apanhou muito, até sangrar. Ainda por cima mergulharamno num barril com sal. Numa "gira" testemunhou-se como, até hoje, a sua proeza e apuros são contados em tom de gozação.

Participam deste grupo, além do Gordo, moleques com nomes como Zeca Capetinha (ou Zezinho do Capeta), Mané da Maconha, Navalha, Pedrinho, Marcelo, Malaquias, Chifrudinho, Chiquinho...

A maioria morreu queimada numa noite fria. Estavam dormindo cobertos por papelão na rua e atearam-lhes fogo, não reagindo por estarem sob o efeito de drogas. Outros foram baleados, estuprados. Sempre tinham droga, porque um deles, o Engomadinho, era filho de um rico traficante.

Segundo nos relataram os sacerdotes que "recebem" o Bananeira e o Caveirinha (Caminhos de Oxalá), a droga, especialmente a maconha, é uma das suas preferências e dá muito trabalho aos terreiros, que precisam "tirá-los do vício". Mas há lugares, contrários à ética umbandista, que se valem deste expediente para mantê-los escravos, prejudicando-os.

Contaram-nos que, nestes casos, se mostram como viciados comuns. Não acatam conselhos nem recomendações morais. Apenas se consegue controlá-los quando são convencidos de que o que se lhes solicita é de interesse do seu próprio eu.

São mesmo muito interesseiros. $\mathrm{Na}$ Casa da Priscila ofereceram-se para cuidar da residência de um casal que fica ao lado de "um desses terrenos baldios, em que adolescentes jogam futebol e fumam maconha". 
Caveirinha alerta: a sua natureza interesseira é igual à humana, e por isso são evitados. Não são diferentes: mostramnos como somos.

Há uma tendência destes personagens para se narrarem como espíritos recentes, o que provavelmente sinaliza a contemporaneidade do agravamento do abandono infantil (esta tendência é contrariada no caso de religiosos que seguem automaticamente a doutrina segundo a qual os "guias" umbandistas, para serem guias, têm de ser espíritos muito antigos). Salvo este constrangimento "teológico", em contextos de expressão menos peada por codificações a contemporaneidade destes "seres" manifesta-se nas narrativas das suas "vidas".

A mãe de santo de um terreiro situado na região norte de São Paulo, mas originalmente estabelecido na Zona Leste (Cacique Pele Vermelha), relata-nos um caso extremo: o seu mirim é desta última parte da cidade e "deve ter uns dez anos de morto. Mais do que isso, não tem”. Apesar das suas décadas de Umbanda, esta senhora incorpora-o há apenas uns quatro anos. "Já via ele comigo, mas não se manifestava". É um espírito novo: "Você vê, ele fala na maconha, fala no batedor de carteira, como se faz hoje. Ele é arisco, tem medo de polícia...".

Quase não vem. A médium mal se lembra do seu nome, consultando circunstantes para poder confirmá-lo como Joãozinho. "Se você vê ele, ele é muito bonzinho, uma figura de moleque de rua. É moreno, não é negro. Treze ou quatorze anos, mais ou menos. Era batedor de carteira".

Apesar de "guia" da mãe de santo, não exerce o comando da sua "linha", pois "não tem chefia", respondendo diretamente, ele e os da mesma categoria, ao exu "adulto" chefe da casa, Toquinho (um "mano grande", apesar do diminutivo que carrega no nome).

Do mesmo terreiro, Manezinho Tição também morava numa favela, só que na região da Casa Verde. Ele e o seu parceiro Risadinha já "em vida" eram do mesmo bando. Não tinham o que comer. Compravam bala e vendiam num farol. Achavam mais fácil roubar. Sobrava bala para o outro dia e levavam dinheiro para casa. Assaltavam perto do farol. "Manezinho empurrava e Risadinha pegava".

Foi morto por um "canela preta" (policial). Foi enterrado como indigente. A mãe só soube depois de sete dias. Ela não ligava para o fato de ele não ir à escola e roubar, pois levava um pouco de dinheiro para casa. Como o dinheiro era pouco, preferia enganar a fome com droga. Nunca gostou de escola e não sabe ler nem escrever. "Tem" 11 anos e tinha muitos irmãos, alguns ainda vivos, sendo cada um de um pai diferente...

Além de crônica social de (maus) costumes, a capacidade de ironizar a própria tragédia e de encontrar alegria no meio da desgraça humana são talentos e procedimentos que esta "linha" traz para os rituais e a experiência psicológica e religiosa umbandista. A alegria, têm-na em comum com as crianças da direita, apenas que subtraída da "inocência" e "pureza" que a acompanha naquelas.

Ora se apresentam como ladrões de galinha, ora como filhos da puta, às vezes as duas coisas e literalmente. A história do "mano" Caveirinha enuncia essa condição. Viveu em algum puteiro de Minas, antes do surgimento dos "pés de borracha" (automóveis). Nasceu num prostíbulo, mas não digam que é filho de uma quenga, porque ele não o aprecia. Define-se como filho de uma "alma caridosa", expressão que aprendeu se aplicar bem a quem "dá”. A mãe atendia os fregueses em cima da cama e ele, escondido debaixo, esgueirava-se para esvaziar os bolsos dos clientes.

O que mais o deixou frustrado na sua curta existência foi não ter alcançado o objetivo de, com essa poupança, comprar a sua "leitoinha" (menina de rua nascido no prostíbulo, cuidadosamente criada para ser leiloada, ao atingir o "primeiro sangue", a puberdade). Morreu aos nove anos, trespassado pelas costas por uma navalha, tentando escapar de um cliente que o havia descoberto. Caiu "na lama" e lá ficou, sem ser enterrado. Com o tempo (Tempo?) virou Caveirinha.

O chefe do seu bando é o Mirim da Bananeira. Tem este nome porque já morava numa destas plantas, no quintal da casa do seu médium, ainda antes dele nascer. Esta "casa" úmida, além de revelar suas competências mágicas e rituais, alude às circunstâncias de sua vida pobre e rural. Morreu de tuberculose, aproximadamente aos 13 anos. Roubava as galinhas dos vizinhos para trazer comida para casa. Nunca matou, só fazia traquinagens.

Pelo mesmo terreiro, muito animado, acaba de passar uma "coleção de ossinhos". Mesmo sem ainda ter licença de dizer o nome, conta-o tal como lho impingiram numa visita a outro centro (Mirim da Encruza). A sua "desobediência" revela-os como são, expeditos e dados a expedientes, ilustrando recursos e talentos desenvolvidos para sobreviver em condições hostis.

Jovial, define-se como o maior pé de dança da encruza, mas nada mais, por enquanto, pode narrar. Entidade de médium em desenvolvimento, rapidamente, numa gira subseqüente, desmente o nome anterior ("era mentirinha") e em sintonia com a percepção a seu respeito de autoridade do seu terreiro, se redefine mais numa linha de cemitério (outra "região", embora haja intersecções, do sagrado umbandista).

Não pode dizer o nome, mas todo o mundo já sabe que é "uma caveira". O Bananeira contou. "Sai fumaça por tudo". Ao comer, também "sai" comida. É osso. "Sou todo ossinhos". Por isso precisa ter algo na cabeça para cobrir. Ganhou uma bandana vermelha e preta. 
As oscilações narrativas, além de típicas de uma manifestação mutante do sagrado que se subsume na categoria "trickster" do orixá Exu, perfazem metamorfoses ao serviço da sobrevivência em condições inóspitas, senão impossíveis, e também manifestam o tatear intrínseco à construção pessoal do médium (portanto são mais comuns nas fases iniciais do chamado "desenvolvimento mediúnico").

A agilidade, mobilidade e mutabilidade características destes "espíritos" expressam-se não apenas nas suas narrativas, mas também em ato na sua ação e interação religiosa com os interlocutores. Freqüentemente jocosos, questionam o pesquisador quanto ao crédito que podem merecer os seus depoimentos... Mas precisamente por "mentirem", em verdade se revelam. Mostram-se como "são" e como refletem o humano, fiéis à sua "natureza", ao se apresentarem pouco confiáveis.

Estes “mortos" infantis “são" fogo! Já foi anteriormente dito que a maioria do grupo que freqüenta a Casa da Priscila encontrou o fim da sua vida em chamas, ateadas pela crueldade social circundante, e que um deles se "deixou ver" com uma cabeleira de labaredas vermelhas. Na mesma linha, diversos integrantes do bando do Mirim da Bananeira têm nomes que aludem ao "arder" (como Pimentinha, Espetinho), provavelmente alusivos ao orixá Exu e especialmente ao seu cunho ígneo.

Fumacinha é exímio em trazer obsessores. Ligeiro, sai e volta do seu médium, de cada vez despejando um deles num integrante da corrente. Brasinha morreu carbonizado. Fazia muitas estripulias e certa vez ateou fogo ao lugar onde estava e virou pó (cinza). Era órfão e as pessoas idosas que com ele ficavam nem sempre podiam tomar conta dele adequadamente. Aprontava e foi vitima da sua imprudência. Hoje, literalmente degusta chamas. Costuma saboreá-las mastigando brasas, apagando cigarros na língua, ou ingerindoas em nacos obtidos "acendendo" um dedo molhado de pinga numa vela.

Como sempre, o sagrado umbandista, além de humano, é performática e superlativamente eloqüente: além do limite da vida, a criança tragicamente carbonizada, reduzida a cinzas, transcende "espiritualmente" a estúpida morte e revela-se ser essencialmente flama e incorruptível ao fogo. O sem sentido ganha sentido e a impotência inverte-se especularmente em poder, literal e metaforicamente associado ao ponto final de uma existência (pudemos testemunhar que, "incorporado" por ele, o médium, de fato, não se queima).

Provavelmente esta marca ígnea assinala a sua afinidade com o orixá Exu, mas o repertório meditativo umbandista não deixa de cogitar outras hipóteses, que mais se somam do que se opõem à mais evidente. Por exemplo, correlacionaos também com a qualidade de fogo associada à justiça e às letras (Xangô). Num dos terreiros colaboradores ressalta-se o seu talento para esconder e fazer aparecer documentos e papéis, bem como outras coisas miúdas: "negócio de documentos..., exu mirim esconde que ninguém acha, não acha mesmo".

Potencialmente birrentos, os exus mirins também não medem conseqüências. Quais delinqüentes juvenis, operam como tropa de choque ou olheiros. Vão na frente. Fazem o trabalho mais difícil, o que ora explicam por, enquanto crianças, não chamarem a atenção (não despertarem suspeitas), ora, nas palavras de Manezinho Tição, por os grandes serem "cheios de capa, cheios de cu" (calcularem limites, o que thes soa como cobardia).

Tipicamente se lhes confiam tarefas tremendas, que exigem tropa de choque disposta a não medir conseqüências e que não seriam aceites por mais ninguém, bem como a segurança de pessoas e bens que circulam na rua. A falta de senso do limite e a preferência por motos e carros podem ser interpretadas como significando-os caracteristicamente juvenis.

O seu apelo ofensivo por reconhecimento e inclusão, afinal, pode equivaler-se razoavelmente aos conflitos de uma individualidade em afirmação, em choque contra o meio familiar e já se aventurando fora dele.

Em reforço desta hipótese há o fato de o imaginário umbandista espelhar em profundidade o humano e saber-se que a maioria dos colaboradores e dos próprios entrevistados assinala a sua idade no princípio da adolescência ( 9 a 13 anos), embora não haja unanimidade quanto a isso.

Outro marco na mesma direção é a importância da sexualidade, esfera de competência da esquerda, mas, no caso deles, sempre muito presente, mas pouco integrada. Entre o escracho e o platônico, é mais falada do que vivida, tipicamente adolescente.

Parece, portanto, que a sua ligação com o fora de casa e o estar na rua é também drástica e claramente marcada como adolescer, eventualmente precoce. Separações dos pais, desapontamentos com famílias e passagens de casa para a rua enquanto traços comuns constituintes da identidade destes personagens, podem estar sendo sobredeterminados pela possibilidade desta categoria, a par de refletir um drama social, tender a desdobrar-se em hierofania tutelar da adolescência. Poderiam aludir a uma característica de liminaridade entre a criança e o adulto, entre a casa e a rua.

O seu deslocamento para a adolescência também equacionaria um pouco melhor o conflito entre a tradicional aversão das "entidades da esquerda" ao ingênuo e infantil, e a admissão de uma categoria no seu meio que também gosta de doces, embora os misture com comidas e bebidas ardentes.

Com esta manobra, que afinal equivale a um sutil raciocínio, estabelece-se uma ponte entre a anomia social (exclusão de crianças) e um processo natural de desenvolvimento, 
mais profundo, humanizando a resistência dos adolescentes normais a leis e reconhecendo a natureza profundamente social e até carinhosa dos agressivos da rua, assimilada a comum rebeldia juvenil.

De fato, nos terreiros que os cultuam, há sérios indícios de que a adolescência poderia vir a definir-se como o setor da sua específica competência para lidar com o humano, o maior dos quais é a coincidente recomendação em dois dos que colaboraram de que, para saber deles, a melhor coisa a fazer é falar com os seus íntimos, os adolescentes. Em conversa com médiuns da Casa da Priscila, referem-nos que quem melhor os conhece é uma adolescente filha da mãe de santo. Realmente, quando ela chega, acrescenta entiquecedoras informações. Também na Casa do Mangueira e da Cigana da Rosa são especialmente amigos de um filho adolescente do casal que os incorpora. Durante a entrevista com Caveirinha, este se lhe dirigiu com muita familiaridade, longa e afetuosamente, como se fossem "manos" da mesma tribo (note-se a complexidade e sofisticação psicológicas: é um "adolescente" espiritual incorporado pela mãe, dirigindose cumplicemente ao seu filho adolescente).

Não é raro que sejam muito pretinhos, como é o caso do Manezinho Tição, do Risadinha, do Girinho e do Zeca Capetinha, embora possam assumir qualquer feição de meninos de rua. Como sempre, o imaginário religioso umbandista se mostra atento a realidades sociais e mais inclui os mais excluídos.

É muito rara a aparição de meninas, até porque, por definição, exu é homem. No terreiro do Toquinho contamnos que a antiga mãe de santo, falecida há mais de dez anos, comentava ter conhecido um médium que recebia uma menina que vinha nesta linha. É o único caso de que tiveram notícia ao longo de todo esse tempo, embora Manezinho Tição, do bando desse centro, nos alerte que com eles vem uma menina, que ainda não "baixa" porque não tem "cavalo". A Casa da Priscila foi freqüentada por uma garota, carinhosamente apelidada pelos seus comparsas de "piiitinha" (imitando o som que nos programas televisivos sublinha palavras proibidas, tornando-as mais audíveis). Não vem mais regularmente, pois a sua médium mudou de cidade. A raridade é tamanha que, no terceiro terreiro, arrisca-se uma hipótese para a sua inexistência: uma menina sexualmente vivida, rapidamente se assimilaria a uma pomba-gira. Deixaria de ser criança e passaria a ser mulher.

De fato, já existe no panteão uma categoria de pombasgiras meninas. Mas a manifestação de suas representantes é ainda mais rara do que a dos meninos exus. Segundo a médium do Risadinha, a mesma se referiria a adolescentes mais velhas e ritualmente, quando "baixa", vem na linha das mulheres.

O povo de rua infantil do sexo feminino, portanto, parece mais difícil de situar e desperta maiores hesitações, sendo praticamente invisível. Talvez assim se assinale uma maior dificuldade em assimilar e elaborar imaginalmente a menina de rua, por a sua exposição ao risco de violência e de exploração sexual implicarem presumivelmente condições de vida ainda mais duras e cruéis, e, portanto, em processos de identificação e de interpretação ritual na própria carne de extremos de horror ainda menos suportáveis.

Joãozinho "come" pão com mortadela. Manezinho e um dos Porteirinhas gostam de costelinha. O Risadinha prefere torresminho e o Caveirinha carne moída com berinjela. $\mathrm{O}$ Mirim da Bananeira gosta de pescoço de frango. "Pedem" carnes, mas nunca as nobres. Os do bando do Toquinho apreciam chocolate preto. Girinho é doido por duas marcas: Bis (que a médium também adora) e Diamante Negro (que ela detesta). Na Casa da Priscila trabalham muito com rapadura e pinga. Estão aprendendo a beber cerveja e uísque Buchanan's ("boa cana", interpretam humoradamente), sobras dos adultos. Disputam os restos dos manos grandes e tentam imitá-los. No terreiro do Mangueira adoram pinga com groselha (parece sangue), mas usualmente tomam-na numa cumbuca com melaço. Também aceitam guaraná ou coca cola com pinga (porradinha, preferência de um dos Porteirinhas). Fumam com fissura, disputando bitucas.

Aparece, misturada a alimentos típicos da esquerda (água ardente e carnes, no caso, especialmente a de porco), a significância marcantemente infantil do doce, nada usual na esquerda adulta, e que têm em comum com as crianças da "direita".

Quando não "comem" incorporados, o espaço ritual das oferendas que lhes são dedicadas, geralmente, são jardins sem flores ou mal cuidados, ou as encruzilhadas junto a praças com estas características. Ou seja, lugares que reproduzem os jardins floridos dos paraísos infantis, mas sem o colorido luminoso dos cosminhos (a enunciação plástica do imaginário umbandista é tão eloqüente, que chega a ser redundante).

Uma parcela significativa do culto recusa-se a lidar com eles. Alega não saber como tratá-los. Cogita-os perigosos demais. Por inacessíveis a argumentos racionais, seriam mais tinhosos do que os exus "adultos".

Esta posição deve ser contextualizada pela ambigüidade intrínseca à categoria e pelo efeito que ela produz. Os que a defendem ilustram uma parcela da reflexão coletiva do imaginário social. Participam da elaboração de uma compreensão social profunda da criança excluída, representando o lado da balança que pondera o pavor e crueldade reativos que ela encarna.

O imaginário opera como reflexão social. Em se tratando de dar sentido humano e dignidade religiosa a terríveis e prementes vivências sociais, é totalmente normal que haja ponderações e polarizações. Uma parcela da comunidade 
umbandista empírica "encarna" um lado dos argumentos e outra ilustra as teses contrárias. Assim avança uma reflexão coletiva, que poderá ou não chegar a uma síntese ou decisão.

Muito provavelmente, dada a vocação inclusiva da Umbanda, a palavra final será a da aceitação. Mas esta não pode acontecer imediata e generalizadamente, sob pena de se cortar o processo de reflexão e, acima de tudo, de se impedir que a crueldade, reativa mas efetiva, do animal humano destituído do mínimo imprescindível à vida digna, seja refletida. Neste caso, não se poderia expressar o horror de condições limites e cruéis da existência humana, nem evocar o temor que elas eliciam.

Se não se puder "tocar" este terror, também não será possível reencontrar por trás das garras das vítimas de tão má fortuna a sua ludicidade infantil. Não se estabelecerão pontes de intersecção com os bastidores infernais dos "bons" cidadãos, determinantes de uma responsabilização coletiva e implicação pessoal na desgraça do infanticídio sistemático, físico e psíquico. Será inviável proceder a uma sublimação reparadora da culpa e da dor e fica obstruída a degustação da sublimidade do mal (sem a qual o rancor e a projeção ressentida de almas "puras" e acanhadas conseguem fingir que meros significados do transcendente, por mais açucarados que sejam, possam substituir experiências limites do humano).

A aparente divergência "teórica" entre umbandistas é, ela mesma, uma forma de reconhecimento do horror e inadmissibilidade extremos. É um indício de contacto com a malignidade do desamparo infantil. Por um lado o acolhe com radicalidade, por outro lado não o destitui do traço a que se resumiu a sua capacidade de se fazer levar em conta e se manter não ignorado, em interpelação com o humano: a sua capacidade de provocar medo.

Sempre que têm oportunidade, os mirins compensam o permanente risco de exclusão ritual, reflexo da exclusão social (que no fundo é consubstancial a esta categoria de personagens do panteão), tentando provar-se imprescindíveis e "mostrar serviço".

Além disso, enquanto sem lugar, dão um jeito de se intrometerem, mostrando um talento notável para se fazerem notar. Algumas peripécias de um dos Porteirinhas pesquisados ilustram a sua luta por reconhecimento.

Em terreiro antigamente freqüentado pela sua médium, representativo do argumento imaginal que radicaliza e realça a sua periculosidade, preferindo "ignorá-los", assentara-se a tronqueira (casinha da esquerda), sem que nenhum lugar fosse concedido aos mirins. No dia seguinte o local amanhece com uma pipa vermelha e preta no teto (a pipa é um brinquedo infantil que, por significativa "coincidência", no caso apresentava as cores rituais da "esquerda"). Alguém comenta: "mais exibido do que esse, impossível". Sem que a médium o soubesse, foi-lhe então preparada uma oferenda para que sossegasse (se mantivesse inativo). O "cala boca" consistia em pipoca recoberta por groselha num alguidar. Ela já o suspeitava pela sua "vózinha" que, "na sua cabeça", indagava: "que coisa gosmenta é essa? Acham que vou ficar quieto com isso?" Insatisfeito, quase bate o portão da garagem do terreiro na saída do carro de um dos médiuns mais graduados da casa e fala, de maneira audível por ele e por ela, "oi tio!".

Este moleque nasceu numa fazenda do interior de São Paulo. Sua mãe morreu quando era bebê. O pai trabalhava e ele aprontava: soltava cavalos, roubava galinhas. Quase adolescente, fugiu para São Paulo. Menino de rua, morreu atropelado próximo ao Monumento às Bandeiras (Parque Ibirapuera), ao tentar salvar outra criança.

Em vida, Porteirinha ficava sentado na porteira da fazenda e hoje circula no limite entre a direita e a esquerda por, em toda a sua existência, ter feito uma coisa boa (a única), qual seja salvar a vida de alguém ao preço da sua. Por isso pode transitar entre esferas de competência do além, e noutros lugares.

Mostrou-se, por exemplo, em desenhos de uma criança de quatro anos, e até hoje cuida da sua família, apontando perigos, como uma vez em que, de madrugada, avisou a médium de uma iminente abordagem por outros motoqueiros, o que a fez voltar correndo para o terreiro, encontrando-o aberto por outro integrante da "corrente" ter recebido "um recado" da sua pomba-gira para ficar à porta, aguardando-a.

A sua médium supõe que o nome Porteirinha deva aludir ao limiar entre a vida e a morte, relacionando-o à esfera de sacralidade presentificada na Umbanda pelas coisas do cemitério. Além de doenças, cuida da sua proteção pessoal. O seu primeiro pai de santo ensinou-lhe que uma das coisas que torna difícil o trato ritual com os mirins é que desprezam regras e conveniências sociais, só obedecendo ao médium e à "lei" (à ética umbandista).

Em verdade, por um episódio que relata, pode-se depreender que, pelo menos o "seu", obedece mais à "lei" do que à médium: certa feita, desafiado por uma pomba-gira que visitava o local em que então "trabalhava" e exigiu que se retirasse por detestar crianças (desapreço pelo infantil que é comum na adulta esquerda umbandista e se torna mais um paradoxo e desafio para a inclusão desta categoria), enfrentou-a e não atendeu aos seus apelos para desistir e “desincorporar". Afinal, ele tinha razão. Estava trabalhando na "ordem" da casa e ela não tinha o direito de impor o seu capricho.

Segundo a médium, a pessoa que teria sido faleceu pouco antes do seu nascimento (é de 67). Acompanha-a desde remotamente, primeiro como um ruído e depois como uma voz. Foi identificado na sua adolescência como criança exu 
num centro espírita kardecista, mas já sabia que aquela voz era de criança, pelo seu jeito insistente, infantil. Instada a passar por uma desobsessão por estar ouvindo vozes sem ter passado pelo curso que a habilitaria a tanto, recusou-se a fazê-lo, preferindo ser fiel ao parceiro: "pode ser exu mirim, mas é o meu exu mirim. Não faz mal a ninguém, ninguém mexe nele. Deixa ele quieto".

Fala com muito afeto, o que é comum aos que pagam o preço de incluir estes enjeitados ontológicos, sociais e rituais, e arcam com os ônus e benefícios desta decisão.

No bando do terreiro do Senhor Mangueira encontramos outro Porteirinha (segundo este, os Porteirinhas vêm na linha do Exu Sete Porteiras), muito agradecido àquele chefe pela oportunidade de ali estar trabalhando. Ilustra o lado da moeda da possibilidade de inclusão ritual.

De qualquer modo, a sua história, como não poderia deixar de ser, igualmente relata abandono: o pai morreu quando criança e a mãe arrumou um padrasto que o espancava muito, na cabeça. Já não era bom de juízo e foi ficando pior. Viveu preso numa espécie de galinheiro sem janelas, anos a fio, até que aprendeu a fazer umas coisas com uns franguinhos, ensinadas por visitantes espirituais sintonizados com o seu ódio estuporado e ressentimento. Preparou "uma cama" (armadilha) para esse padrasto, que o antecedeu na ida para o mundo dos mortos... Está informado de que um dia terá de encontrar e perdoar o dito cujo. Espera que esse dia ainda demore bastante...

Mesmos nos terreiros que os acolhem, a sua aceitação não ocorre sem reservas. $\mathrm{Na}$ Casa do Toquinho, por exemplo, a mãe de santo orgulha-se de poder prescindir dos seus serviços: "Graças a Deus eu nunca precisei que eles precisassem ajudar eu em alguma coisa". E explica que "eles trabalham sempre na maldade mesmo" e que "como crianças, não têm noção do que possam fazer".

"Se você pedir, eles fazem. Ele é automático. Ele faz, e depois você tem que trabalhar contra o seu exu mirim mesmo!" Irrefletidamente, "vão num comando, através de uma vela, de um chocolate, qualquer coisa assim. É aonde às vezes escondem coisas que ninguém acha. São perigosos, é preciso saber trabalhar com eles". Os terreiros que com eles lidam, explica-nos, são "os que trabalham com magia". Não é o caso da sua "casa", e, por isso, nunca ou raramente são solicitados.

Atuam como uma matilha. Perigosos, mas ansiosos para "mostrar serviço", segundo o médium do Mirim da Bananeira "são como cãezinhos treinados. Podem ser terríveis, mas, só dependendo de você, são o melhor amiguinho que se pode ter". Andam em gangues.

Nunca se supõe que uma criança "trabalhe" sozinha. A sua inclusão ainda subalterna no culto faz-se patente no fato de não terem autonomia ritual. Trabalham com os grandes e são por eles controlados. Na Casa da Priscila, diz-se que "trabalham" sob vigia.

A atenção à vida alheia é um meio deles "trabalharem". A sua verborragia facilmente descamba em fofoca, pois, insidiosos e penetrantes, conseguem entrar nos mais recônditos e sutis segredos das pessoas e não hesitam em pôr o dedo na ferida. No fundo, tratam os outros como se tratam, como aprenderam a serem tratados.

Linguarudos, não é raro que "entreguem" ao comando do terreiro episódios e "colegas" humanos com os quais se depararam pelas esquinas da vida, especialmente os seus amigos adolescentes (coisas do tipo leitura de revistas para adultos, presença em lugares e rodinhas suspeitas, etc.). Mas a maneira como o fazem é notável por espelhar com sensibilidade a sua comunhão e solidariedade com o censurado. No fundo estavam lá, não para vigiar ninguém, mas porque são iguais. Se houver reprimendas ou punições, eles serão os primeiros a lhes fazer companhia no infortúnio. Os "manos" revelam os vícios como seus advogados. Não são moralistas chatos.

Um misto de gratidão, acolhimento e sentido de aliança profunda são comuns entre os umbandistas que os cultuam.

Apesar de não terem freqüentado escolas, são de fato muito espertos e competentes nos caminhos da vida. Sabem cativar e mostrar eficiência, lutando para obter um lugar definitivo no panteão. Pouco a pouco, vêm cavando essa posição.

No terreiro da Sete Esquinas vêm depois dos exus e pombas giras, quando dá tempo. Mas nos últimos anos passaram a também terem uma festa anual, sinal de prestígio. No entanto, a garantia de definição de um lugar específico para eles ainda está longe de estar assegurada. No último ano (2002), no dia da sua festa, nada havia sido especificamente preparado. Vieram num final de gira de esquerda, sem que nenhuma oferenda ou "agrado" lhes tivesse sido preparado coletivamente com antecedência. Apesar da sua presença nesse terreiro ser comum, a ambigüidade que se lhes devota reproduz-se no seu próprio seio e não se faz segredo na casa de que o mirim da sacerdotisa, Joãozinho, não obstante admitido, seria uma entidade (a única) temida pela prudente mãe de santo que, aliás, nos confirma sem reservas ser este tipo de "espírito" extremamente perigoso e preferir evitá-lo.

$\mathrm{Na}$ Casa do Mangueira a seqüência é a mesma (vêm em terceiro lugar). Sublinha-se que se têm obtido resultados muito bons com o seu trabalho, num tom de franco reconhecimento.

A mesma ordem é seguida na Casa da Priscila, na qual são chamados de erês (denominação que com mais freqüência se encontra associada às crianças da direita, 
mostrando que até do ponto de vista terminológico se encontram divergências a seu respeito). A sua médium diznos que eles "estão se chegando, ganhando o espaço deles". "Desde que entrei na Umbanda, já ouvia falar deles: erês virados, crianças da linha de baixo, mas não se tinha o contato que tem hoje. Começaram a surgir na minha casa. Primeiro o Navalha, o Zezinho do Capeta e mais um. De repente, virou festa agora. Toda a gira de esquerda vem erê". Dar ouvidos às suas histórias permite ver como em profundidade estas crianças são coletivamente compreendidas pelos próprios setores sociais que estão mais próximos delas.

Acrescenta: "A marginalidade hoje é muito mais cara a cara. Já que está aí no mundo material, a gente talvez esteja mais perto dela no mundo espiritual, para saber lidar com ela no mundo material. O próprio plano espiritual vem soltando essa linha no plano espiritual, para que a gente aprenda a lidar com ela no mundo material. Estão aí, não tem como fugir disso. Eles são o retrato vivo da história”.

\section{Discussão}

O progressivo delineamento e consolidação de uma personalidade antiga do panteão de exus (Bittencourt, 1974; Fontenelle, s.d.; Ronton, s.d.) em categoria do sagrado umbandista encarregada de significar a intersecção entre infância e rua (quer na forma cruel do abandono infantil, quer como divindade tutelar do momento de passagem da intimidade do lar para o mundo da rua) permite estudar como acontecimento contemporâneo a manifestação do talento umbandista para enunciar reflexões sociais.

A imagem que o imaginário umbandista constrói da infância "delinqüente" e da rebelião adolescente transmuta experiências de vida infernais em manifestações do sagrado doadoras de benesses. Repete defeitos constatados pelo senso comum que, de Outra perspectiva, se mostram qualidades.

A temeridade inconseqüente desdobra-se em coragem inaudita, a vigarice transforma-se em amizade incondicional, as "voltas cortadas" e a "falta de pé" redundam em extrema agilidade, drogas de vida guardam experiências capazes de orientar caminhos seguros, vidas queimadas revelam-se fogos sagrados, a desvantagem de ser pequeno e despertar indiferença torna-se competência para ser penetrante e sutil, a exclusão social e o temor transmutam-se em re-inclusões espetaculares e surpreendentes, fofocas subsumem-se em compromissos (mesmo ao custo da dor) com a verdade, comidas e vidas de segunda categoria mostram-se amizades imprescindíveis e qualidades de primeira, o periculoso proporciona benesses...

O estatuto dos exus mirins como crias postas fora de casa, crianças na rua, permite-lhes aludir à transição entre a casa e os caminhos do mundo, típica do adolescer e da indefinição de lugar que lhe é consubstancial. Evocam uma oscilação ainda não resolvida entre ternura maternal e erotismo heterossexual, largamente ilustrada por comumente se narrarem como filhos ou adotados por mulheres da rua (filhos da puta, ainda que se trate de uma mera adoção ritual por pombas-giras).

Este passo do espelhamento do enjeitamento social de crianças para a inclusão de momentos universais do desenvolvimento é uma maneira popular de reiterar a normalidade dessas crianças e de compreendê-las como integrantes de pleno direito da família humana, muito semelhantes com quem somos. Isso é feito sem negar o modo potencialmente maldoso de se ser humano e infantil, articulando o seu sentido e funcionalidade ao todo existencial contemporâneo, na forma da sua admissão num enredo narrativo do cotidiano social e de funções rituais.

Os exus mirins mostram-se (espelham) processos de auto-afirmação e lutas por reconhecimento (social, ritual, pessoal...). Vêem ganhando o seu espaço, nem sempre com pleno sucesso. De certa forma o estar fora de lugar élhes consubstancial.

Este estatuto também lhes permite mostrarem-se lugarestenentes do horror do abandono infantil, sinalizando uma ética (ritualmente demonstrada) integradora, não apenas das representações da criança vitimizada e/ou delinqüente, mas principalmente de possibilidades de ser cruéis, sublimadas em epifanias de aspectos da totalidade do corpo social que se entranham em dimensões de cada pessoa, inclusive e principalmente das que os temem.

Sabe-se como se compreendem, ou melhor dizendo, quem "são", pelas suas narrativas, exatamente como a identidade humana se elabora narrativamente.

Palavras são pouco para expressar o que narram, e por isso o imaginário procede incluindo gestos, atos e performances rituais, em busca de alternativas e sentido contemporâneo para a vida em desespero.

Quando isso ainda é pouco, não hesitam em suscitar alucinoses e passagens ao ato, que seriam muito mal compreendidas se se interpretassem psicopatologicamente.

Esse sagrado que se formula em histórias tão mundanas, só grosseiramente poderia ser reduzido a uma tentativa ilusória de compensação para frustrações sociais. Psicólogos e psicanalistas, sabemos que o olhar do outro (e do Outro) é constituinte do humano, e mudanças de perspectiva, dons de novos sentidos, transformam-no. No caso dos mirins deparamo-nos com um caso limite do talento do imaginário social para interferir e tentar reparar imagens mal ditas: o extremo da falta de cuidado (para dizer o mínimo), se reverte em capacidade superlativa para o cuidar. Com isso obviamente não se mudam condições sócio-históricas 
objetivas, mas se contrariam pré-concepções culturais que podem favorecer a sua manutenção.

A Umbanda é uma elaboração a céu aberto de viscerais meditações coletivas. O "seu" imaginário religioso apresentase a si mesmo como entranhado nas possibilidades de quem o "vê", as quais amplia espelhando e alargando as possibilidades de ser do seu interlocutor. Constitui-se numa plataforma útil para o desenvolvimento de uma área de conhecimento na intersecção entre psicologia e antropologia (Augras, 1983, 1995; Devereux, 1969/1996, 1970; Nathan, 1988, 1995), que preferimos denominar etnopsicologia.

Além disso, sensível a dores insuportáveis, o imaginário religioso umbandista induz a práticas de reparação, subjetivas e sociais. Promove uma "partilha" do drama humano, espelhando mutuamente sociedade e excluídos, vítimas e algozes, e mostrando uns e outros numa mesma solidariedade, humana e criminosa.

A "missão" dos mirins é equacionar terror e encanto, ódio e gratidão. Conjugam atrocidade com sublimidade em todos e com todos, sem exclusão ou opressão, psicológica nem social.

Ressoam uma experiência limite de crueldade humana contra o humano. Sublimam o impensável horror do desabrigo e desamparo, precocemente imposto a seres ainda "sem pernas" para se "virarem" sozinhos.

Propiciam o manejo de um trauma social e abuso extremo, com efeitos de "cura", não propriamente de fatos sociais objetivos (embora relativamente a estes os umbandistas desenvolvam trabalhos de cuidado e culto do "povo de rua" literalmente presentificado em grupos sociais concretos, entre os quais crianças de rua), mas do olhar que lhes é dirigido, habitualmente retorcido, quer por pavor e rejeição, quer por sentimentos de piedade e percepções de carência.

Estes, no fundo, partem do pressuposto inconsciente de que o outro seria muito aceitável desde que se transformasse, que deixasse de ser o que é, que se extinguisse, num ataque frontal raramente percebido como proposta de extermínio, embalada em boas intenções.

$\mathrm{Na}$ direção contrária, a cultura popular, mais próxima destas vivências, segue o caminho da compaixão: o "ethos" da Umbanda não se pauta pela exclusão de nada nem de ninguém. Promove a inclusão tal e qual do socialmente abortado (em múltiplos níveis). Encontra na dor e na morte uma sobrevida que restitua sentido a experiências contemporâneas e vivências lancinantes, bem como uma forma sublimada de acolhimento do desespero, que equacione formas de responder a novos gritos e apelos (que podem formular-se muito para além do verbal e em termos aparentemente contraditórios).

A sua inclusividade expressa-se no fato de geralmente os remédios para males éticos ou sociais deverem consistir numa reconversão do sentido de tipos humanos que se supõem especialistas no mal a tratar.

Desta forma é possível valorizar o "criminoso" e cruel na sua qualidade. Admitir aspectos desagradáveis e assustadores do humano, sem o suprimir nem humilhar, quer nos ameace na nossa própria auto-imagem, quer nos aborde feito outro numa esquina da cidade. Para "incorporá-lo", é preciso reconhecê-lo, social e ritualmente.

Portanto, o sagrado umbandista, ao proporcionar uma imagem de si, também cuida e repara a imagem social de setores atingidos por descriminações e estigmas ferozes. Acolhe a insistência do oprimido e elabora uma compreensão do ser social, psiquicamente reparadora de maus tratos cravados na carne da existência humana e de cicatrizes lavradas na memória coletiva. Não é uma coleção estática de símbolos, mais ou menos complexos, mas antes uma linguagem, finamente enunciada. Sublima histórias mundanas e biografias humanas plausíveis em narrativas com o valor performativo de operações religiosas (Paula Carvalho, 1998). Concede (ou revela) dignidade e sentido ao aparentemente insignificante ou absurdo.

Obviamente esse sagrado, em seu estatuto de linguagem, não pode escutar-se com os olhos que buscam verificar a verdade de proposições objetivas. É preciso desistir de ouvir realistamente o que nos narra, e a sua enunciação não faz segredo de que almejá-lo seria perseguir falsas pistas (familiares crianças de rua podem espelhar-se em estranhos seres ígneos e ambos reunirem-se em relatos de vidas que se transcendem em enunciações cifradas de ritos). A sua expressividade superlativa não se subordina a pretensões descritivas de supostas realidades, nem estritamente históricas nem objetivamente metafísicas. Já previamente as interpreta como ficções portadoras de mensagens implícitas para os seus interlocutores contemporâneos (as comunidades que o celebram e todo e qualquer um que lhe dê ouvidos).

De fato, aquém de ecoar um Outro misterioso e especulativo, descomprometido com realismos, a elaboração umbandista da "criança diaba" é concomitantemente um processo de reflexão social do abandono infantil. Dá conta da experiência limite de uma crueldade contra o humano e promove a inclusão de suas presas e agentes, dando-lhe sentido.

Entre memória e reflexão, nas entranhas sociais reflete infernalmente mandamentos do céu. Quebra-galhos, os "erês virados", "crianças de baixo", "caem" e "se quebram". Apodrecem "na lama”. Estas imagens, que aparentemente refletem julgamentos sobre metafísicas pessoas, são ponderações teatralmente "ilustradas" de juízos sobre ações possíveis para todos, incluído cada interlocutor, na forma de modelos exemplares de defeitos virtuosos, ou da limitação de virtudes... 
Cada narrativa atribuída a nome ou categoria de "espíritos" resume um argumento, traçado dramaticamente, cujo real alcance depende do contexto global do panteão e das suas interações.

Cada característica que possa adjetivar o humano e as suas possíveis condições, sintetizadas pela experiência histórica e a memória social, é elaborada em tipos extremamente humanos, capazes de se constituírem em apelos à aceitação do rejeitado, psíquica e/ou socialmente, ao revelarem em plenitude hipóteses sobre a qualidade e conseqüências dos seus defeitos. Sem cada uma dessas possibilidades a humanidade continuaria inocente, incompleta, ou boba. A Umbanda concretiza uma tentativa de harmonização do psiquicamente contraditório, fundida a uma argumentação em prol da interdependência entre destinos contemporâneos e sobreposta a uma interpretação do transcendente, que o propõe como ressoante da humanidade e aberto aos seus meandros, a ponto de que não se exclua nenhuma humana possibilidade de ser.

Os terreiros, em rede imaginal, servem como continente de elaboração desta experiência e missão coletiva, proporcionando um rico campo para o desenvolvimento de uma psicologia social dialógica, em profundidade.

\section{Referências}

Augras, M. (1995). Alteridade e dominação no Brasil: Cultura e psicologia. Rio de Janeiro: Nau.

Augras, M. (1983). O duplo e a metamorfose: A identidade mítica em comunidades nagô. Rio de Janeiro: Vozes.

Bairrão, J. F. M. H. (2000). Clínica e sociedade: O que será um psicanalista? Boletim Formação em Psicanálise, 9(2), 7-22.

Bairrão, J. F. M. H. (2001). A imaginação do Outro: Psicanálise e hierologia. Paidéia - Cadernos de Psicologia e de Educação, 11(21), 11-26.

Bairrão, J. F. M. H. (2002). Subterrâneos da submissão: Sentidos do mal no imaginário umbandista. Memorandum: Memória e História em Psicologia, 2, 5567. http://www.fafich.ufmg.br/ memorandum/artigos02/bairrao01.htm

Bittencourt, J. M. (1974). No reino dos exus. Rio de Janeiro: Eco.

Brumana, F. G. \& Martinez, E. G. (1991). Marginália sagrada. Campinas: Editora da Unicamp.

Concone, M. H. V. B. (2001). Caboclos e pretos-velhos na Umbanda. Em R. Prandi (Org.), Encantaria brasileira: O livro dos caboclos, mestres e encantados (pp. 281-303). Rio de Janeiro: Pallas.
Concone, M. H. V. B. (1987). Umbanda, uma religião brasileira. São Paulo, SP: CERUSP/EDUSP.

Corbin, H. (1977a). Face de Dieu, face de l'bomme. Paris: Flammarion.

Corbin, H. (1977b). L'imagination créatrice dans le soufisme d'Ibn'Arabi. Paris: Flammarion.

Corbin, H. (1979). Corps spirituel et Terre céleste: De l'Iran mazdéen à l'Iran shîite. Paris: Buchet/Chastel.

Corbin, H. (1981). Le paradoxe du monothéisme. Paris: Éditions de l'Herne.

Corbin, H. (1990). L'Iran et la philosophie. Paris: Fayard.

Devereux, G. (1970). Essais d'ethnopsychiatrie générale. Paris: Gallimard.

Devereux, G. (1996). Ethnopsycbiatrie des Indiens Mohaves. Paris: Les Empêcheurs de penser en rond. (Original publicado em 1969)

Duarte, L. F. D. (1984). Grupo e singularidade: Uma reflexão antropológica sobre um texto de Freud. Religião e Sociedade, 11(2), 138-145.

Dumont, L. (1997). Homo Hierarcbicus. São Paulo: EDUSP. (Original publicado em 1992)

Dumont, L. (2000a). Homo aequalis. Bauru: EDUSC. (Original publicado em 1977)

Dumont, L. (2000b). O individualismo: Uma perspectiva antropológica da ideologia moderna. Rio de Janeiro: Rocco. (Original publicado em 1983)

Fontenelle, A. (s.d.). Exu. Rio de Janeiro: Espiritualista.

Goldman, M. (1984). A possessão e a construção ritual da pessoa no candomblé. Dissertação de Mestrado não-publicada, Programa de Pós-graduação em Psicologia Social, Museu Nacional, Universidade Federal do Rio de Janeiro. Rio de Janeiro, RJ.

Goldman, M. (1996). Uma categoria do pensamento antropológico: A noção de pessoa. Revista de Antropologia, 39, 83-109.

Lacan, J. (1966). Écrits. Paris: Éditions du Seuil.

Mauss, M. (1968). Une catégorie de l'esprit humain: la notion de personne, celle de moi. Em Sociologie et Anthropologie. Paris: PUF.

Nathan T. (1988). Le Sperme du Diable. Eléments d' ethnopsychothérapie. Paris: P.U.F.

Nathan T. (1995). Psychanalyse païenne. Paris: Odile Jacob.

Negrão, L. N. (1996). Entre a cruze a encruzilhada: Formação do campo umbandista em São Paulo. São Paulo: Edusp.

Paula Carvalho, J. C. (1998). Imaginário e Mitodologia: Hermenêutica dos símbolos e estórias de vida. Londrina: Editora UEL.

Prandi, R. (1991). Os candomblés de São Paulo. São Paulo: Hucitec.

Ronton, J. (s.d.). Trabalhos de Umbanda-Canjerê. São Paulo: Ícone.

Souza, A. R. (2001). Baianos, novos personagens afro-brasileiros. Em Reginaldo Prandi (Org.), Encantaria brasileira: O livro dos caboclos, mestres e encantados (pp. 304-317). Rio de Janeiro: Pallas.

Trindade, L. (1985). Exu, poder e perigo. São Paulo: Ícone.

Winnicott, D. W. (1975). O brincar e a realidade. Rio de Janeiro: Imago.

Winnicott, D. W. (1990). Natureza bumana. Rio de Janeiro: Imago.

Sobre o autor

José Francisco Miguel Henriques Bairrão é Psicólogo e Filósofo, Doutor em Filosofia pela Universidade de Campinas. É Professor de Psicologia Social da Faculdade de Filosofia, Ciências e Letras de Ribeirão Preto da Universidade de São Paulo. 


\section{NÚCLEO DE ESTUDOS E PESQUISA EM TRANSTORNOS \\ DO DESENVOLVIMENTO - NIEPED}

Filiado ao Programa de Pós-graduação em Psicologia do Desenvolvimento - UFRGS

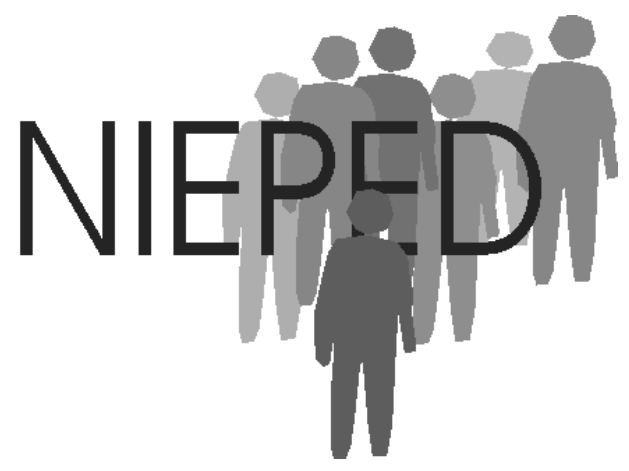

O NIEPED congrega psicólogos e demais profissionais das áreas da saúde e educação interessados na investigação e compreensão dos transtornos do desenvolvimento e suas implicações para intervenção na comunidade.

Os objetivos do NIEPED são: Desenvolver pesquisa sobre crianças e adolescentes que apresentam transtornos do desenvolvimento, com ênfase no comprometimento psicolingüístico e da interação social, e aspectos psicossociais; criar um banco informatizado de dados e referências bibliográficas sobre a área, disponível para pesquisadores, estudantes e profissionais interessados no assunto; incentivar o desenvolvimento e circulação de instrumentos de avaliação do comportamento da população estudada para fins clínicos, educacionais, e de pesquisa, bem como a elaboração de material bibliográfico destinado a professores, familiares e profissionais em geral; apoiar e subsidiar estudos e intervenções transdisciplinares, públicas ou privadas, com a finalidade de desenvolver programas educacionais e de qualificação profissional visando a melhoria das condições de vida dessas crianças/adolescentes e suas famílias; atuar no ensino da graduação e pós-graduação.

NIEPED / UFRGS

Instituto de Psicologia

Rua Ramiro Barcellos 2600, 110

CEP 90035003

Fone: (51) 33165449

www.psicologia.ufrgs.br/nieped 